\title{
Effect of Chronic Nifedipine Treatment on Blood Pressure and Adrenergic Responses of Isolated Mesenteric Artery in Young Rats with Developing Spontaneous Hypertension
}

\author{
A. ZEMANČÍKOVÁ, J. TÖRÖK \\ Institute of Normal and Pathological Physiology, Slovak Academy of Sciences, Bratislava, Slovak \\ Republic
}

Received October 30, 2009

Accepted November 23, 2009

\section{Summary}

It is documented that in chronic hypertensive state there is an increased vasodepressor response to calcium channel antagonists such as the dihydropyridine derivate nifedipine. This effect is generally proportional to initial blood pressure as was demonstrated in several models of experimental hypertension. In the present study we investigated the effect of chronic nifedipine treatment on the development of cardiovascular system in young spontaneously hypertensive rats (SHR) in order to evaluate whether it could prevent the abnormalities leading to hypertensive state. Four- and eight-week-old rats were treated with nifedipine ( $50 \mathrm{mg} / \mathrm{kg} /$ day) for 4 weeks. Blood pressure of nifedipine-treated SHR remained at the initial level in contrast to their untreated controls where it continued to increase. In both age groups, chronic nifedipine administration reduced neurogenic contractions of isolated superior mesenteric artery, but did not significantly affect the dose-response curve to exogenous noradrenaline in 8-week-old rats. In contrast, maximum response to noradrenaline was significantly attenuated in mesenteric artery of 12-week-old nifedipine-treated SHR. We can presume that the antihypertensive effect of nifedipine is similar in both stages of spontaneous hypertension development, but the mechanisms involved might be different. It seems that chronic reduction of calcium influx during the rapid phase of pathological blood pressure increase in SHR may eliminate the effect of enhanced sympathetic tone, which may have unfavorable consequences on cardiovascular structure and function.

\section{Key words}

SHR • Ontogenesis • Nifedipine • Sympathetic nervous system

\section{Corresponding author}

A. Zemančíková, Institute of Normal and Pathological Physiology, Slovak Academy of Sciences, Sienkiewiczova 1, 81371 Bratislava, Slovak Republic. E-mail: anna.zemancikova@savba.sk

Spontaneously hypertensive rats (SHR) are frequently used experimental model in the study of numerous cardiovascular abnormalities accompanying sustained blood pressure elevation. Like essential hypertension in humans, this rat strain is characterized by enhanced total vascular resistance, which is a result of many functional and structural alterations in blood vessel wall. The data obtained from in vivo and in vitro studies suggest that there is an increased sensitivity to calcium ions and to vasodepressor action of calcium channel antagonists like the dihydropyridine derivate nifedipine (Boonen and De Mey 1990, Kähönen et al. 1994, Matsuda et al. 1997, Kubo et al. 1998). It is well known that these calcium channels mediate voltage-dependent calcium influx into vascular smooth muscle cell being responsible for the major part of its tonic contraction. Therefore the changes of smooth muscle cell membrane potential (depolarization and hyperpolarization) seem to be very effective way for vascular tone regulation. Noradrenaline, the main neuromediator of sympathetic nervous system, increases vascular smooth muscle tension through several simultaneously acting intracellular mechanisms, many of them leading to the stabilization of open state of voltage-dependent calcium channels whereby account for the tonic part of

PHYSIOLOGICAL RESEARCH • ISSN 0862-8408 (print) • ISSN 1802-9973 (online)

(c) 2009 Institute of Physiology v.v.i., Academy of Sciences of the Czech Republic, Prague, Czech Republic

Fax+420 241062 164, e-mail: physres@biomed.cas.cz, www.biomed.cas.cz/physiolres 
Table 1. Systolic blood pressure and relative heart weight in 8- and 12-week-old untreated Wistar and SHR as well as in age-matched SHR treated for 4 weeks with nifedipine $(50 \mathrm{mg} / \mathrm{kg} / \mathrm{day})$.

\begin{tabular}{|c|c|c|c|c|c|c|}
\hline & \multicolumn{3}{|c|}{$8^{\text {th }}$ week } & \multicolumn{3}{|c|}{$12^{\text {th }}$ week } \\
\hline & $\begin{array}{l}\text { Wistar } \\
(\mathrm{n}=8)\end{array}$ & $\begin{array}{l}\text { SHR } \\
(n=6)\end{array}$ & $\begin{array}{c}\text { Nifedipine- } \\
\text { treated SHR } \\
(n=6)\end{array}$ & $\begin{array}{l}\text { Wistar } \\
(n=6)\end{array}$ & $\begin{array}{l}\text { SHR } \\
(n=6)\end{array}$ & $\begin{array}{c}\text { Nifedipine- } \\
\text { treated SHR } \\
\quad(n=7)\end{array}$ \\
\hline $\begin{array}{l}\text { Systolic blood pressure } \\
(\mathrm{mm} \mathrm{Hg})\end{array}$ & $107.3 \pm 2.9$ & $143.4 \pm 0.9$ & $113.8 \pm 4.0^{* * *}$ & $115.5 \pm 4.5$ & $180.6 \pm 4.2$ & $129.4 \pm 6.2^{* * *}$ \\
\hline $\begin{array}{l}\text { Relative heart weight } \\
(\mathrm{mg} / \mathrm{g})\end{array}$ & $3.35 \pm 0.07$ & $5.75 \pm 0.07$ & $3.96 \pm 0.06^{* * *}$ & $2.83 \pm 0.05$ & $3.95 \pm 0.15$ & $3.53 \pm 0.06^{*}$ \\
\hline
\end{tabular}

Data represent mean values \pm S.E.M. Relative heart weight is a ratio of heart weight $(\mathrm{mg})$ and body weight $(\mathrm{g}) . \mathrm{n}=$ number of animals in each group. $* \mathrm{P}<0.05, * * * \mathrm{P}<0.001$ for nifedipine-treated SHR vs. untreated age-matched SHR.

noradrenergic contraction (Nelson et al. 1988).

Paulis et al. (2007) pointed out the relationship between the abnormal function of L-type voltagedependent calcium channels and the increased tone of the sympathetic nervous system in SHR and experimentally demonstrated the enhancement of nifedipine-sensitive component of noradrenergic contraction in this rat strain. The described effect was also found in other experimental models like salt hypertension in Dahl rats or NO-deficient hypertension (Kuneš et al. 2004) which are characterized by enhancement of sympathetic system as well (Zicha et al. 2001, Pecháñová et al. 2004). This indicates that the increased participation of voltage-dependent calcium channels in the maintenance of high blood pressure might not be exclusively associated with genetic abnormalities of these channels but it may be related to their abnormal activation by enhanced sympathetic tone (Paulis et al. 2007).

In SHR, rapid blood pressure increase over the values of age-matched control Wistar rats occurs mainly between the $3^{\text {rd }}$ and $10^{\text {th }}$ week of life and is also accompanied by maturation processes in cardiovascular sympathetic neurotransmission. Simultaneously, an augmented and widespread pressure-dependent cardiovascular hypertrophy occurs. Many authors suggest that elimination of pressure-induced or humorally mediated structural alterations in cardiovascular system during this period might attenuate the severity of developing hypertension and its related complications (Zicha and Kuneš 1999).

In the present study we investigated the effect of long-term nifedipine treatment in young SHR to prevent the pathological increase of their blood pressure and the abnormal vessel reactivity. Four- and eight-week-old
SHR were treated with nifedipine $(50 \mathrm{mg} / \mathrm{kg} /$ day, given in chow) for 4 weeks (i.e. from $4^{\text {th }}$ to $8^{\text {th }}$ week and from $8^{\text {th }}$ to $12^{\text {th }}$ week of age). Untreated Wistar rats served as normotensive control. Systolic blood pressure was measured noninvasively by tail plethysmographic method. At the end of the chronic treatment, the animals were sacrificed and superior mesenteric artery was isolated for in vitro experiments. The ring segments of this artery were prepared and mounted in tissue baths for measurement of isometric contractile force. Vasoconstrictor responses were elicited by noradrenaline applied cumulatively into the bathing solution or by endogenous noradrenaline released from perivascular sympathetic nerve terminals during transmural electrical stimulation. Presented results are expressed as mean values \pm S.E.M.

Basal blood pressure of untreated 4-week-old SHR at the beginning of the experiment was $111.6 \pm 4.8$ $\mathrm{mm} \mathrm{Hg}$ (similar to blood pressure of 4-week-old Wistar rats $-104.6 \pm 1.3 \mathrm{~mm} \mathrm{Hg}$ ) and after 4 weeks it gradually increased to $143.4 \pm 0.9 \mathrm{~mm} \mathrm{Hg}$. Blood pressure of untreated 8-week-old SHR was $143.1 \pm 4.3 \mathrm{~mm} \mathrm{Hg}$ before the experiment and after 4 weeks it was elevated to $180.6 \pm 4.2 \mathrm{~mm} \mathrm{Hg}$ (Table 1). In both nifedipine-treated groups, the rise of blood pressure was eliminated; it means that nifedipine completely prevented its further elevation. Resultant values of blood pressure were smaller by $21 \%$ and $28 \%$ in the $8^{\text {th }}$ and $12^{\text {th }}$ weeks of age, respectively, compared to untreated SHR. Heart weight to body weight ratio was increased in untreated SHR compared to Wistar rats indicating myocardial hypertrophy. This ratio was smaller in all nifedipinetreated rats (Table 1) which also reflects the diminished blood pressure load in these animals. In both age groups, chronic nifedipine administration reduced neurogenic 


\section{$8^{\text {th }}$ week}

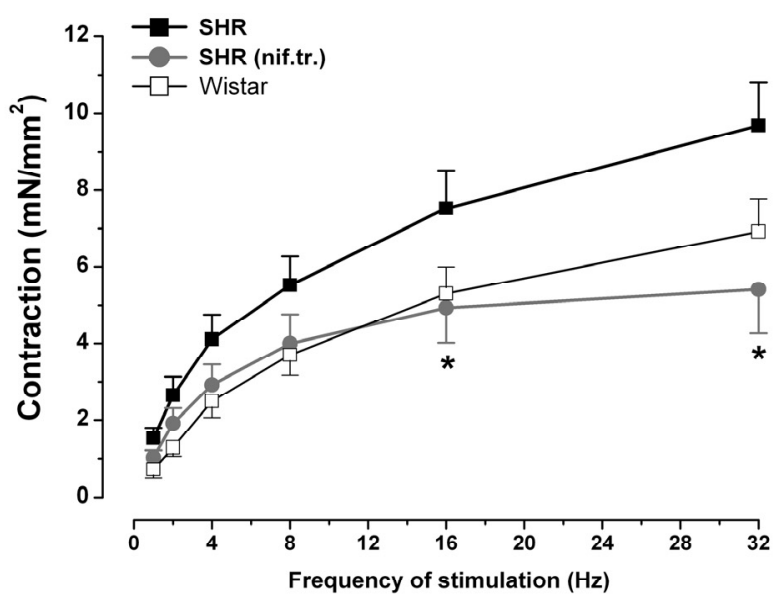

$12^{\text {th }}$ week

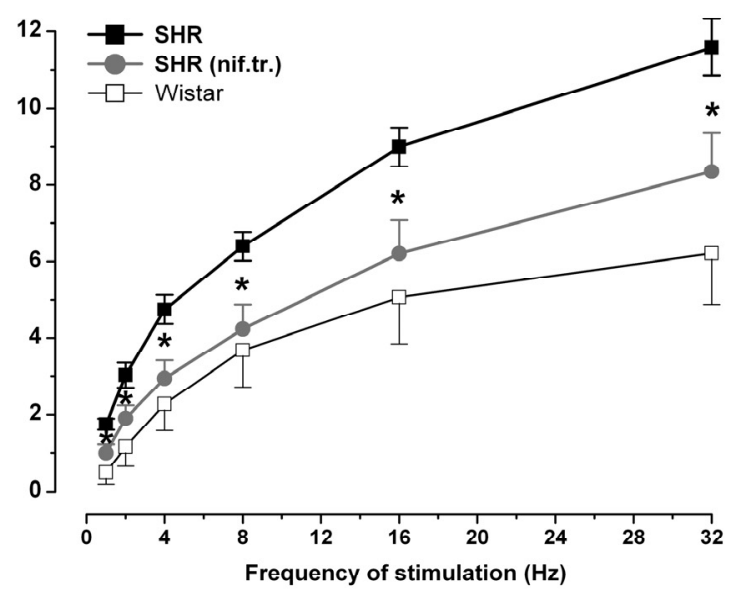

Fig. 1. Frequency-dependent neurogenic contractions of the superior mesenteric artery from control normotensive Wistar rats ( $\square$ ), untreated SHR ( $\mathbf{\square})$ and nifedipine-treated SHR (๑). Symbols represent means \pm S.E.M. from 6-9 vessel preparations in each group. $* \mathrm{P}<0.05$ vs. SHR.

\section{$8^{\text {th }}$ week}

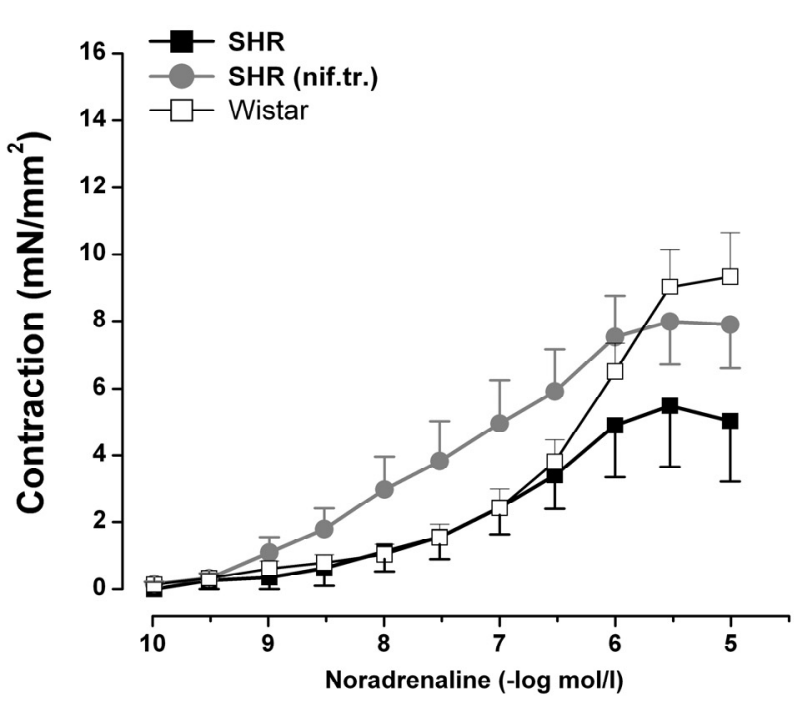

\section{$12^{\text {th }}$ week}

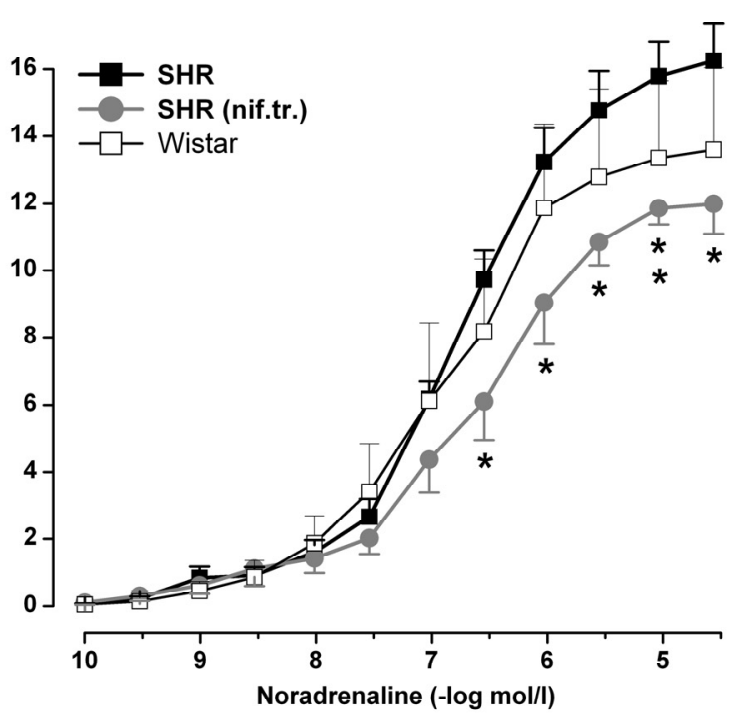

Fig. 2. Concentration-response curves for exogenous noradrenaline-induced contraction of the superior mesenteric artery from control Wistar rats $(\square)$, untreated SHR $(\square)$ and nifedipine-treated SHR $(\bullet)$. Symbols represent means \pm S.E.M. from 6-9 vessel preparations in each group. * $\mathrm{P}<0.05 ; * * \mathrm{P}<0.01$ vs. SHR.

contractions of isolated superior mesenteric artery, but in 8 -week-old rats this reduction reached significance only when high frequencies of transmural electrical stimulation were used (Fig. 1). Moreover, nifedipine did not importantly affect the dose-response curves to exogenous noradrenaline in this younger group, although slight leftward shift was detected. In contrast, mesenteric artery of 12-week-old nifedipine-treated SHR reached significantly lower values in maximum contractile response to noradrenaline, while its sensitivity to noradrenaline remained unchanged (Fig. 2).

On the basis of the described results it seems that the antihypertensive effect of nifedipine is similar in both stages of spontaneous hypertension development, but the mechanisms involved might be different. In our experiments, nifedipine treatment importantly affected adrenergic mechanisms in superior mesenteric artery since the contractions to endogenous noradrenaline 
(neurogenic contractions) were significantly reduced in both age groups of SHR. This reduction was percentually corresponding to that of exogenous noradrenaline response in 12-week-old rats indicating that nifedipine influences sympathetic vasoconstriction predominantly at the level of vascular smooth muscle. Chronically decreased calcium influx into smooth muscle cells not only reduces the excessive vascular tone, but it also prevents the hypertrophic processes in arterial wall which is particularly important from the long-term point of view (Ko et al. 1992, Hérembert et al. 1995). The structural changes may account for the decline in maximum contractile response to noradrenaline while the sensitivity was not affected.

On the other hand, the effect of chronic nifedipine treatment on adrenergic contractions was not so evident in 8-week-old SHR, although blood pressure decrease was not much different from that in the older group. This may be in part the consequence of the voltage-dependent nature of the blocking action of calcium channel antagonists (Morel and Godfraind 1987, Nelson and Worley 1989). It means that under the conditions of the more depolarized smooth muscle cell membrane potential, detected in long-term experimentally induced elevation of transmural pressure (Harder 1984) or in chronic hypertensive state of SHR (Morel and Godfraind 1994, Kiyoshi et al. 2006), the calcium blocking agents are more capable to influence the voltage-dependent calcium channel function. Around the weaning period in rat (i.e. from the $3^{\text {rd }}$ to $5^{\text {th }}$ week of age), SHR are still normotensive and therefore we can presume that the electrophysiological properties of the smooth muscle cell membrane may not be affected yet. This was also documented in other studies (Wanstall and O'Donnell 1989, Hernández et al. 1995) in which the calcium channel antagonist-induced relaxation of arterial rings precontracted with noradrenaline was investigated in hypertensive rats. The vasodepressor response was greater in older animals in which hypertension was already established.

In our experiments, in SHR treated with nifedipine from the $4^{\text {th }}$ to $8^{\text {th }}$ week of age the reduction only in neurogenic contractions was observed, which might indicate also other mechanism in the modulation of sympathetic vasoconstriction. Several authors confirmed that calcium channel antagonists including the dihydropyridine derivates inhibit the vascular contractile responses to transmural nerve stimulation also by the attenuation of endogenous noradrenaline release from sympathetic nerve endings (Takata and Kato 1984; Jayakody et al. 1986). The inhibition of the release of noradrenaline as a neurotransmitter from these structures appeared to be due to the partially non-specific interference with presynaptic calcium channels, which represent the different class of calcium channels from those localized in vascular smooth muscle cells. The described mechanism might also participate in our case when the chronic restriction of endogenous noradrenaline in synaptic cleft in the vessel wall could lead to the partial increase in the sensitivity of the smooth muscle adrenergic receptor system.

There are also other possible effects of calcium channel antagonists which can contribute to the antihypertensive action of nifedipine in SHR of both ages, like the up-regulation of nitric oxide system (Ding and Vaziri 2000) or the pressure-independent growthinhibitory effect on cardiovascular structures (Hérembert et al. 1995).

In conclusion, we have shown that long-term treatment of young SHR with calcium antagonist nifedipine decreased the increment of their blood pressure comparably in both stages of developing hypertension. It seems that during the rapid phase of pathological blood pressure increase in SHR chronic reduction of calcium influx may eliminate the effect of enhanced sympathetic tone which may have unfavorable consequences on cardiovascular structure and function.

\section{Conflict of Interest}

There is no conflict of interest.

\section{Acknowledgements}

The study was supported by grants VEGA No. 2/6150/28 and 2/0193/09, Slovak Republic.

\section{References}

BOONEN HC, DE MEY JG: Increased calcium sensitivity in isolated resistance arteries from spontaneously hypertensive rats: effects of dihydropyridines. Eur J Pharmacol 179: 403-412, 1990.

DING Y, VAZIRI ND: Nifedipine and diltiazem but not verapamil up-regulate endothelial nitric-oxide synthase expression. J Pharmacol Exp Ther 292: 606-609, 2000. 
HARDER DR: Pressure-dependent membrane depolarization in cat middle cerebral artery. Circ Res 55: 197-202, 1984.

HÉREMBERT T, ZHU DL, MARCHE P: Mechanism of action of the inhibitory effect of nifedipine on the growth of cultured aortic cells from spontaneously hypertensive and normotensive rats. Br J Pharmacol 114: 1703-1709, 1995.

HERNÁNDEZ MC, SALAICES M, ARRIBAS S, SÁNCHEZ-FERRER CF, MARÍN J: Influence of age on the relaxation induced by nifedipine in aorta from spontaneously hypertensive and Wistar Kyoto rats. $J$ Auton Pharmacol 15: 379-392, 1995.

JAYAKODY RL, KAPPAGODA CT, SENARATNE MP: Effect of calcium antagonists on adrenergic mechanisms in canine saphenous veins. J Physiol Lond 372: 25-39, 1986.

KÄHÖNEN M, ARVOLA P, WU X, PÖRSTI I: Arterial contractions induced by cumulative addition of calcium in hypertensive and normotensive rats: influence of endothelium. Naunyn-Schmiedebergs Arch Pharmacol 349: 627-636, 1994.

KIYOSHI H, YAMAZAKI D, OHYA S, KITSUKAWA M, MURAKI K, SAITO SY, OHIZUMI Y, IMAIZUMI Y: Molecular and electrophysiological characteristics of $\mathrm{K}^{+}$conductance sensitive to acidic $\mathrm{pH}$ in aortic smooth muscle cells of WKY and SHR. Am J Physiol 291: H2723-H2734, 2006.

KO YD, SACHINIDIS A, GRAACK GH, APPENHEIMER M, WIECZOREK AJ, DÜSING R, VETTER H: Inhibition of angiotensin II and platelet-derived growth factor-induced vascular smooth muscle cell proliferation by calcium entry blockers. Clin Investig 70: 113-117, 1992.

KUBO T, TAGUCHI K, UEDA M: L-type calcium channels in vascular smooth muscle cells from spontaneously hypertensive rats: effects of calcium agonist and antagonist. Hypertens Res 21: 33-37, 1998.

KUNEŠ J, HOJNÁ S, KADLECOVÁ M, DOBEŠOVÁ Z, RAUCHOVÁ H, VOKURKOVÁ M, LOUKOTOVÁ J, PECHÁŇOVÁ O, ZICHA J: Altered balance of vasoactive systems in experimental hypertension: the role of relative NO deficiency. Physiol Res $\mathbf{5 3}$ (Suppl 1): S23-S34, 2004.

MATSUDA K, LOZINSKAYA I, COX RH: Augmented contributions of voltage-gated $\mathrm{Ca}^{2+}$ channels to contractile responses in spontaneously hypertensive rat mesenteric arteries. Am J Hypertens 10: 1231-1239, 1997.

MOREL N, GODFRAIND T: Prolonged depolarization increases the pharmacological effect of dihydropyridines and their binding affinity for calcium channels of vascular smooth muscle. J Pharmacol Exp Ther 243: 711-715, 1987.

MOREL N, GODFRAIND T: Selective interaction of the calcium antagonist amlodipine with calcium channels in arteries of spontaneously hypertensive rats. J Cardiovasc Pharmacol 24: 524-533, 1994.

NELSON MT, STANDEN NB, BRAYDEN JE, WORLEY JF: Noradrenaline contracts arteries by activating voltagedependent calcium channels. Nature 336: 382-385, 1988.

NELSON MT, WORLEY JF: Dihydropyridine inhibition of single calcium channels and contraction in rabbit mesenteric artery depends on voltage. J Physiol Lond 412: 65-91, 1989.

PAULIS L', LÍŠKOVÁ S, PINTÉROVÁ M, DOBEŠOVÁ Z, KUNEŠ J, ZICHA J: Nifedipine-sensitive noradrenergic vasoconstriction is enhanced in spontaneously hypertensive rats: the influence of chronic captopril treatment. Acta Physiol (Oxf) 191: 255-266, 2007.

PECHÁŇOVÁ O, DOBEŠOVÁ Z, ČEJKA J, KUNEŠ J, ZICHA J: Vasoactive systems in L-NAME hypertensive rats: the role of inducible nitric oxide synthase. J Hypertens 22: 167-173, 2004.

TAKATA Y, KATO H: Effects of Ca antagonists on the norepinephrine release and contractile responses of isolated canine saphenous veins to transmural nerve stimulation. Jpn J Pharmacol 34: 397-409, 1984.

WANSTALL JC, O'DONNELL SR: Influence of age on calcium entry blocking drugs in rat aorta is spasmogendependent. Eur J Pharmacol 159: 241-246, 1989.

ZICHA J, KUNEŠ J: Ontogenetic aspects of hypertension development: analysis in the rat. Physiol Rev 79: 1227-1282, 1999.

ZICHA J, DOBEŠOVÁ Z, KUNEŠ J: Relative deficiency of nitric oxide-dependent vasodilation in salt hypertensive Dahl rats: the possible role of superoxide anions. J Hypertens 19: 247-254, 2001. 